\title{
Project Financial Post Evaluation Model Design Based on Cash Value Added Theory
}

\author{
WANG Shengyu, LI Tao \\ School of Economics and management, North China Electric Power University \\ Changping District, Beijing, China
}

\begin{abstract}
The number of projects invested by Chinese enterprises is rising rapidly, enterprises are facing overcapacity, resource redundancy and other issues. Project post evaluation method can fix deviations from the feasibility assessment, thus, the value of the project can be maintained. In accordance with the relevance between project performance evaluation and cash movement, the concept of "Cash Value Added" (CVA) is proposed with its theoretical foundation, calculation method and driving factors. A new post evaluation model based on CVA which combines discounted cash model with actual operating cash flow is designed. The financial situation of the project is analyzed from the perspectives of measuring current earning ability, assessing surplus value, revising internal return rate, and finding driving factors, the new model is an effective evaluation tool in line with the actual situation.
\end{abstract}

Keywords—project post evaluation, cash value added, financial benefits, cash management

\section{INTRODUCTION}

Investment project post evaluation is a technical and economic analysis tool that refers to the project performance evaluation method based on feasibility research, actual operations and projected earnings after the project has been put into use for a period of time. With the improvement of China's enterprise management theory as well as the development of the market economy practice, the financial post evaluation system is becoming more and more mature. The existing project financial post evaluation index system is mainly constructed from the aspects of solvency, operation ability and profitability, which covers almost all aspects of project operation that basic to meet the needs of stakeholders. But we also have to admit that there are some problems in current project post evaluation work: cash is the blood of an enterprise it is a damage to the enterprise value if only has the book proceeds without actual cash income. Establishing an effective financial post evaluation model that focuses on cash flow will minimize the risk of enterprise fraud.

Swedish scholars Erik Ottosson and Fredrik Weissentieder formally proposed the concept of Cash Value Added (CVA) in 1996, as in [1]. CVA is a new type of financial performance evaluation model based on the type of investment classification, which focuses on the cash flow of enterprises. CVA has the foundations of value management and the general advantages of discounted cash measurement models, e.g. it can connect the existing investment and potential investment, intuitively reflect the gap between actual profit and investors expected. CVA has drawn greater attention in China, [2] think the CVA indicators are good for enterprise performance analysis when enterprises in mergers and acquisitions period, [3] combines the advantages of multiple indicators to establish a new index for enterprise value evaluating named VA.

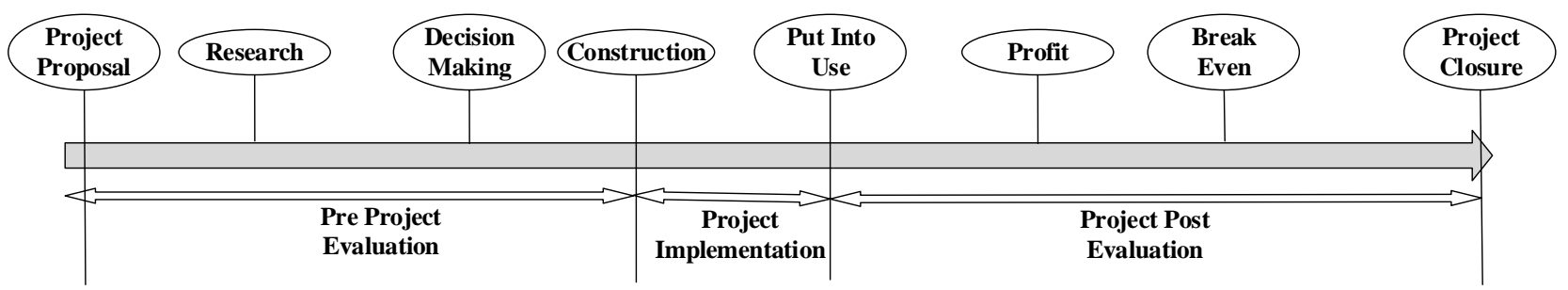

Fig. 1. The Time Axis of the Whole Process of Enterprise Project Evaluation

In this paper, the concept of CVA is introduced into the project financial post evaluation, creating a new model mainly focuses on cash flow, which enriches the current financial post evaluation system. The new model compares the actual operating cash flow of the project with the investors' request for return, providing a simpler approach to value ability to create value of a project, in the same time, it is also helpful to make more scientific and rational decisions for managers.

\section{OVERVIEW OF CVA THEORY}

\section{A. The Concept of CVA}

CVA is a cyclical net present value model that divides enterprise investment into strategic investment and nonstrategic investments, where strategic investments are investments that can create or influence enterprise value, and 
non-strategic investments are the costs designed to maintain the value of strategic investments.

Unlike the economic value added (EVA) model, the CVA model not only includes enterprise profit and capital costs, but also takes investors' expected profits into account. CVA focuses on the performance of cash flow, in the same time, as a comprehensive evaluation tool, it combines the advantages of free cash flow model and enterprise value management theory, innovates enterprise performance evaluation methods, connects the project feasibility prediction and actual operation results, making the performance evaluation method base on cash flow more feasible [4].

\section{B. The Calculation Method of CVA}

\section{1) Operating cash flow}

Operating cash flow (OCF) is the actual cash flow generated during the operation of the project. It has three key factors: Operating Surplus (OS), Change in Net Working Capital (CNWC) and Non-strategic Investment (NI).Among them, the project profit refers to earnings before interest, tax and depreciation (EBDIT), the working capital refers to the current assets purchased by long-term liabilities, the net operating capital in the narrow sense is the difference between current assets and current liabilities.

The formula of OCF, i.e.,

$$
O C F=O S \pm C N W C-N I=E B D I T-O C \pm C N W C-N I
$$

In (1), OC is the cash cost of sales.

\section{2) Operating cash flow demand}

Operating cash flow demand (OCFD) is the expected cash flow of investors to the project. In CVA model, assuming that OCFD is a set of constant and equal amount cash flow distributed in the strategic investment cycle, the sum of the OCFD present value which uses weighted average cost of capital as the discount rate, is equal to the initial investment amount (IA) of the project, i.e. the net present value of OCFD is zero [5].

$$
O C F D=I A \times\left[\frac{r}{1-(1+r)^{-n}}\right]
$$

In enterprise practice, the inflation rate is changing constantly. According to the actual inflation rate during the previous period, the dynamic adjustment of the OCFD before calculation should be carried out to ensure the validity and reliability of the prediction.

\section{3) $C V A$}

CVA is the difference between OCF and OCFD, which can effectively assess whether the actual cash flow of the investment during the period is higher or lower than the investor's expectation. CVA can be used for various periods of business, making it possible to compare the same type of project established at different times.

$$
C V A_{1,2, \ldots, n}=O C F_{1,2, \ldots, n}-O C F D_{1,2, \ldots, n}
$$

When CVA>0, the actual cash flow in the current period exceeds the investor's expectation, proving that the strategic investment has created a new value [6], the project is worth continuing to be invested; when $\mathrm{CVA} \leq 0$, indicating that the investment damaged the enterprise value, it should be rectified or be stopped.

The total NPV of a strategic investment is equal to the sum of all discounted CVA in every period. Only when CVA $>0$, the NPV of the project is likely to be positive, i.e. the project can bring benefits to the enterprise. According to [1], the financial links are as (4):

$$
\begin{aligned}
N P V & =P V\left(O C F_{1,2, \ldots, n}\right)-I A=P V\left(O C F_{1,2, \ldots, n}\right)-P V\left(O C F D_{1,2, \ldots, n}\right) \\
& =\left[\frac{O C F_{1}}{(1+r)}+\ldots+\frac{O C F_{n}}{(1+r)^{n}}\right]-\left[\frac{O C F D_{1}}{(1+r)}+\ldots+\frac{O C F D_{n}}{(1+r)^{n}}\right] \\
& =\frac{O C F_{1}-O C F D_{1}}{(1+r)}+\ldots+\frac{O C F_{n}-O C F D_{n}}{(1+r)^{n}} \\
& =\frac{C V A_{1}}{(1+r)}+\ldots+\frac{C V A_{n}}{(1+r)^{n}}
\end{aligned}
$$

In line with the production and operation process, multistep computation method for CVA is summarized as Tab.1:

TABLE I. MULTISTEP COMPUTATION METHOD FOR CVA

\begin{tabular}{|c|c|c|c|c|}
\hline Factors & Operation & Period 1 & $\ldots$ & period n \\
\hline Revenue & $(+)$ & & $\ldots$ & \\
\hline Cost & $(-)$ & & $\ldots$ & \\
\hline Operating Surplus & & & $\ldots$ & \\
\hline Net Working Capital Movement & $(+)$ & & $\ldots$ & \\
\hline Non-strategic Investments & $(-)$ & & $\ldots$ & \\
\hline Operating Cash Flow & & & $\ldots$ & \\
\hline Operating Cash Flow Demand & $(-)$ & & $\ldots$ & \\
\hline Cash Value Added & & & $\ldots$ & \\
\hline
\end{tabular}

\section{4) CVA index}

CVA index is another dimension of CVA, emphasizing a model building logic that OCFD must be included in the OCF after the project is put into operation, providing a criterion for enterprises' project post evaluation of the same project in different periods or different projects during the same period.

$$
C V A \text { Index }=\frac{O C F_{i=1,2, \ldots, n}}{O C F D_{i=1,2, \ldots, n}}
$$

When CVA Index $>1$, the project can produce enough OCF to maintain operations; when CVA Index $\leq 1$, the project cannot meet the expectations of investors, managers need to rectify the project in time.

CVA Profitable Index is the most comprehensive assessment formula which assess the level of profitability and income-generating capacity of investment projects from the perspective of the economic life cycle.

$C V A$ Profitable Index $=\frac{P V\left(O C F_{i=1,2, \ldots, n}\right)}{P V\left(O C F D_{i=1,2, \ldots, n}\right)}=\frac{P V\left(O C F_{i=1,2, \ldots, n}\right)}{I A}$ 


\section{NEW MODEL DESIGN BASED ON CVA THEORY}

In order to take advantages of cost-benefit management, the design work of new model follows principles of scientific, systematic, dynamic, reliability and economy, evaluating projects from a cash perspective.

\section{A. Basic Elements}

Based on the CVA theory, the new model involves 6 basic elements of operating profit: net working capital changes, nonstrategic investment, initial investment (i.e. IA), discount rate and economic life cycle, which mainly focus on the cash operating capacity of the project [7].

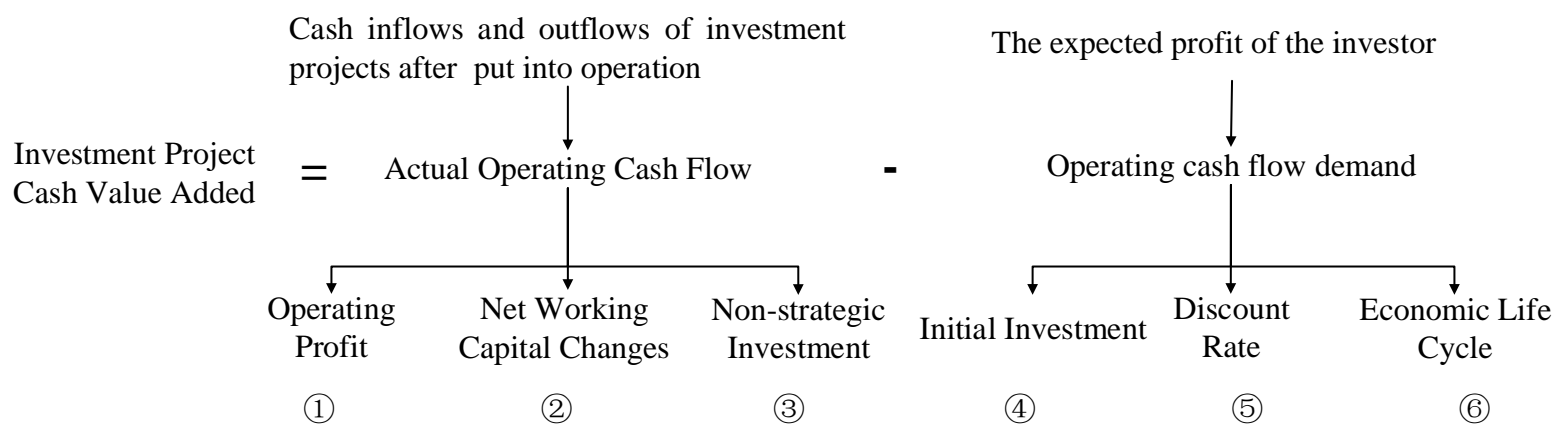

Fig. 2. Analysis of the Basic Elements of Project Post evaluation Model Based on CVA

\section{B. Main Content}

1) Measure project value creation ability

By calculating CVA and CVA index to compare the actual and expected gap, adjust the future expected value, thus minimize the error. The contents of the evaluation include the following aspects:

- Comparison of OCF expected values with OCF actual values.

- Comparison of OCF actual values and OCFD.

- Comparison of CVA index expected values with CVA index actual values.

- Comparison of NPV of OCF actual values and NPV of OCFD.

2) Estimate project future surplus value

The future surplus value of the project is equal to the product of the future CVA index and the corresponding OCFD, i.e. the present value of the future OCF.

It is a scientific method to predict project surplus value by using simulation software such as neural network [8]. Project current cash flow is a helpful material to forecast future CVA index, after this, at least $\mathrm{N}(\mathrm{N} \geq 3)$ expected future $\mathrm{CVA}$ will be used to calculate future surplus value (at least $\mathrm{N}$ ) of the project. If all of the forecast values are within the investor's expectation, the project prospects is better.
TABLE II PROJECT RESIdUal Value Calculation

\begin{tabular}{|c|c|c|c|c|}
\hline Calculation Item & \multicolumn{4}{|c|}{ Predictive Value } \\
\hline \multirow{2}{*}{ Estimated Future CVA Index } & PlanA & PlanB & $\ldots$ & PlanX \\
\cline { 2 - 5 } & $\mathrm{a}$ & $\mathrm{b}$ & $\ldots$ & $\mathrm{x}$ \\
\hline Future OCFD Present Value & \multicolumn{5}{|c|}{$\mathrm{P}$} \\
\hline Estimated Residual Value & $\mathrm{aP}$ & $\mathrm{bP}$ & $\ldots$ & $\mathrm{xP}$ \\
\hline Average Estimated Residual Value & \multicolumn{5}{|c|}{$(\mathrm{aP}+\mathrm{bP}+\ldots+\mathrm{xP}) / \mathrm{X}$} \\
\hline
\end{tabular}

3) Correct the internal rate of return

In the CVA model, OCFD is a set of cash flows when NPV is zero, so the capital cost rate in the project feasibility report is the predicted internal rate of return (IRR). In the actual operation process, the actual OCF is used to do project trend analysis, thus, the value of future net operating cash flow and IRR are corrected.

\section{4) Find a breakthrough in improving efficiency}

CVA index can be decomposed into the following four drivers: OS, CNWC, NI, OCFD. Since OCFD is the expected cash flow determined by the investor's own assessment, only the first three driving factors could be analyzed by factor analysis approach. The lower right angle "1" in the formula means actual value and the lower right angle "0" means predicted value.

TABLE III. SENSITIVITY ANALYSIS BASED ON FACTOR ANALYSIS APPROACH

\begin{tabular}{|c|c|c|}
\hline Factors & Formula & Influence \\
\hline $\mathrm{OS}$ & {$\left[\left(O S_{1}-O S_{0}\right) \pm C N W C_{0}+N I_{0}\right] \times \frac{1}{O C F D_{0}}$} & $\Delta=\left(O S_{1}-O S_{0}\right) \times \frac{1}{O C F D_{0}}$ \\
\hline $\mathrm{CNWC}$ & {$\left[O S_{1} \pm\left(C N W C_{1}-C N W C_{0}\right)+N I_{0}\right] \times \frac{1}{O C F D_{0}}$} & $\Delta= \pm\left(C N W C_{1}-C N W C_{0}\right) \times \frac{1}{O C F D_{0}}$ \\
\hline $\mathrm{NI}$ & {$\left[O S_{1} \pm C N W C_{1}+\left(N I_{1}-N I_{0}\right)\right] \times \frac{1}{O C F D_{0}}$} & $\Delta=\left(N I_{1}-N I_{0}\right) \times \frac{1}{O C F D_{0}}$ \\
\hline
\end{tabular}




\section{Meanings and Fuctions}

Traditional project evaluation methods lead managers to waste too much time in controlling and evaluating nonstrategic investments. In the CVA model, the decision-making of enterprises can be divided into two kinds (non-strategy decision and strategy decision), this new post evaluation model will be better to help managers understand and distinguish the focus of enterprise investment [9-10].

In addition, in the development trend of management automation, managers gradually lose their sensitivity to financial data, the new model will guide them to apply financial data more flexible, meanwhile, and the important role of financial information can also be fully played out.

\section{CONCLUSION}

Based on the theoretical framework of the whole process of investment project, this paper introduces the CVA theory into project financial post evaluation system, and establishes a new financial post evaluation model based on CVA, which is highly comprehensive and practical. As a cyclical NPV model, CVA takes into account the financial time value and the actual cash profit, which effectively compensate the shortcomings of existing financial post evaluation system. It is beneficial for the stakeholders to understand operation status of projects, and is more conducive to managers to find problems and shortcomings in time.

The project post evaluation model based on CVA theory is of great helpful to enterprises' judgement on operating performance and surplus value of a project, which also fit the goal of shareholder value maximization, is an effective evaluation tool in line with the actual situation.

\section{REFERENCES}

[1] Ottosson E, Weissenrieder F. Cash Value Added - A New Method For Measuring Financial Performance[J]. Ssrn Electronic Journal, 1998.

[2] JIANG Shuo, DING Shuang. Reserch on Value Creation of Mergers Based on Cash Value Added Theory-A Case Study of Merger between Geely and Volvo[J]. Finance and Accounting Mouthly, 2014(17) : 5558(In Chinese).

[3] Qin E. New Indicators of Enterprise Value Evaluation VA Based on EVA and CVA[J]. Modern economic information,2015(23):162-163(In chinese).

[4] DU Huijun.Research on post - evaluation method of fixed assets investment project [M]. Economic Management Press, 2012(In chinese).

[5] KUANG Chaoqiong. A Post-Financial Post-evaluation of A Grid Engineering [D].The Institute for Fiscal Science Research ,Ministry of Finance of P.R.China,2015(In chinese) .

[6] LIANG Ce. Construction of financial post - evaluation model for power grid project [J]. Journal of North China Electric Power University (Social Science Edition), 2016, (06): 23-28(In chinese).

[7] WU Yunna, FAN Liang, CHEN Kaifeng. Post-evaluation of Economic Benefits of Power Grid Projects with Consideration of Relevance[J]. Electric Power,2016,49(12):156-161(In Chinese).

[8] Hayden F G. Project Evaluation in a Future's Real Time System[J]. Journal of Economic Issues, 2016, 15(2):401-411.

[9] Lorenc $\mathrm{S}$. The economic value of the enterprise for stakeholders in the fuel and energy sector[J]. Energy and Fuels. 2017, 14:01008.

[10] Sadeghi Moghaddama S, Talebbeydokhti A. A study on relationship between the information of cash value added and return of stocks: An empirical investigation on accounting profit, free cash flow and Tobin's Q[J]. Management Science Letters, 2014, 4(1):117-122. 